\title{
Phytoprotection
}

\section{Effectiveness of carbon dioxide in compressed gas or solid formulation for the control of insects and mites in stored wheat and barley}

\author{
N.D.G. White et D.S. Jayas
}

Volume 74, numéro 2, 1993

URI : https://id.erudit.org/iderudit/706040ar

DOI : https://doi.org/10.7202/706040ar

Aller au sommaire du numéro

Éditeur(s)

Société de protection des plantes du Québec (SPPQ)l

ISSN

0031-9511 (imprimé)

1710-1603 (numérique)

Découvrir la revue

Citer cet article

White, N. \& Jayas, D. (1993). Effectiveness of carbon dioxide in compressed gas or solid formulation for the control of insects and mites in stored wheat and barley. Phytoprotection, 74(2), 101-111. https://doi.org/10.7202/706040ar
Résumé de l'article

Le bioxyde de carbone peut être utilisé comme un fumigant efficace des grains entreposés dans des mini-silos relativement étanches. $\mathrm{Du}_{\mathrm{CO}_{2}}$ a été ajouté à du blé (Triticum aestivum) sous forme de gaz comprimé, ainsi qu'à de l'orge (Hordeum vulgare) sous forme solide (glace sèche) dans des amas de grains de $322 \mathrm{~kg}$. Le blé a été entreposé à une température passant de 18 à $10^{\circ} \mathrm{C}$ au cours d'une période de 12 semaines. Les mini-réservoirs de blé ont été laissés ouverts, scellés sans ajout de $\mathrm{CO}_{2}$ ou avec ajout de $\mathrm{CO}_{2}$, à des concentrations de 25,34 ou $46 \%$. L'orge a été entreposé à une température passant de 25 à $20^{\circ} \mathrm{C}$ au cours d'une période de 8 semaines. Les mini-silos d'orge ont été laissés ouverts, scellés sans ajout de $\mathrm{CO}_{2}$ ou avec ajout de $\mathrm{C}_{2}$, à des concentrations de 23, 29 ou 34\%. Les teneurs en humidité du blé et de l'orge ont été de 14,5-16,3\% et de $14,5-16,1 \%$, respectivement. Les teneurs en $\mathrm{O}_{2}$ du blé ont reflété le déplacement de l'air par le $\mathrm{CO}_{2}$; cependant les niveaux plus faibles de $\mathrm{CO}_{2}$ dans l'orge ont reflété une combinaison du déplacement de l'air par le $\mathrm{CO}_{2}$ et de l'utilisation d' $\mathrm{O}_{2}$ pour la respiration des grains et des microorganismes aux températures plus élevées. Les insectes Cryptolestes ferrugineuset Tribolium castaneum ont été réprimés en 2 semaines à $34 \%$ de $\mathrm{C}_{2}$ et $15 \%$ d'02 à une température passant de 18 à $10^{\circ} \mathrm{C}$, ou à $29 \%$ de $\mathrm{C}_{2}$ et $3 \%$ d'02 à une température passant de 25 à $20^{\circ} \mathrm{C}$. Les acariens Tarsonemus granarius, Lepidoglyphus destructor et Aeroglyphus robustus ont été réprimés en moins de 2 semaines à ces concentrations de $\mathrm{C}_{2}$. La germination des grains et la microflore n'ont pas été affectées par tous ces environnements gazeux.
Ce document est protégé par la loi sur le droit d'auteur. L'utilisation des services d’Érudit (y compris la reproduction) est assujettie à sa politique d'utilisation que vous pouvez consulter en ligne.

https://apropos.erudit.org/fr/usagers/politique-dutilisation/ 


\title{
Effectiveness of carbon dioxide in compressed gas or solid formulation for the control of insects and mites in stored wheat and barley
}

\author{
N.D.G. White ${ }^{1}$ and D.S. Jayas ${ }^{2}$
}

Received 1992-11-09; accepted 1993-07-27

Carbon dioxide can be used as an effective stored-grain fumigant in relatively air-tight bins. Carbon dioxide was added to wheat (Triticum aestivum) as a compressed gas and to barley (Hordeum vulgare) as a solid (dry ice) in 322$\mathrm{kg}$ grain bulks. Wheat was stored at temperature decreasing from 18 to $10^{\circ} \mathrm{C}$ over a 12-wk period. Bins were left open, sealed without $\mathrm{CO}_{2}$ added, or with $\mathrm{CO}_{2}$ supplemented at 25,34 , and $46 \%$ levels. Barley was stored at temperature decreasing from 25 to $20^{\circ} \mathrm{C}$ over an 8-wk period. Bins were left open, sealed without $\mathrm{CO}_{2}$ added, or with $\mathrm{CO}_{2}$ treatments of 23,29 , and $34 \%$. The wheat and barley moisture content were $14.5-16.3 \%$ and $14.5-16.1 \%$, respectively. Oxygen levels in the wheat reflected air displacement with $\mathrm{CO}_{2}$, but lower $\mathrm{O}_{2}$ levels in the barley reflected a combination of air displacement by $\mathrm{CO}_{2}$ and consumption of $\mathrm{O}_{2}$ by respiring grain and microorganisms at the warmer temperatures. The insects Cryptolestes ferrugineus and Tribolium castaneum were controlled in $2 \mathrm{wk}$ at $34 \% \mathrm{CO}_{2}$ and $15 \% \mathrm{O}_{2}$ at temperature decreasing from 18 to $10^{\circ} \mathrm{C}$, or $29 \% \mathrm{CO}_{2}$ and $3 \% \mathrm{O}_{2}$ at temperature decreasing from 25 to $20^{\circ} \mathrm{C}$. The mites Tarsonemus granarius, Lepidoglyphus destructor, and Aeroglyphus robustus were killed in less than $2 \mathrm{wk}$ at these $\mathrm{CO}_{2}$ levels. Seed germination and microflora were unaffected by all gaseous environments.

White, N.D.G. et D.S. Jayas. 1993. Efficacité du bioxyde de carbone sous forme gazeuse ou solide pour la lutte aux insectes et acariens dans le blé et l'orge entreposés. PHYTOPROTECTION 74: 101-111.

Le bioxyde de carbone peut être utilisé comme un fumigant efficace des grains entreposés dans des mini-silos relativement étanches. $\mathrm{Du} \mathrm{CO}_{2}$ a été ajouté à du blé (Triticum aestivum) sous forme de gaz comprimé, ainsi qu'à de l'orge (Hordeum vulgare) sous forme solide (glace sèche) dans des amas de grains de $322 \mathrm{~kg}$. Le blé a été entreposé à une température passant de 18 à $10^{\circ} \mathrm{C}$ au cours d'une période de 12 semaines. Les mini-réservoirs de blé ont été laissés ouverts, scellés sans ajout de $\mathrm{CO}_{2}$ ou avec ajout de $\mathrm{CO}_{2}$, à des concentrations de 25,34 ou $46 \%$. L'orge a été entreposé à une température passant de 25 à $20^{\circ} \mathrm{C}$ au cours d'une période de 8 semaines. Les mini-silos d'orge ont été laissés ouverts, scellés sans ajout de $\mathrm{CO}_{2}$ ou avec ajout de $\mathrm{CO}_{2}$, à des concentrations de 23,29 ou $34 \%$. Les teneurs en humidité du blé et de l'orge ont été de 14,5$16,3 \%$ et de 14,5-16,1\%, respectivement. Les teneurs en $\mathrm{O}_{2}$ du blé ont réflété le déplacement de l'air par le $\mathrm{CO}_{2}$; cependant les niveaux plus faibles de $\mathrm{CO}_{2}$

1. Agriculture Canada, Research Station, 195 Dafoe Road, Winnipeg, Manitoba, Canada R3T 2 M9. Contribution no. 1517.

2. Department of Agricultural Engineering, University of Manitoba, Winnipeg, Manitoba, Canada R3T 2N2 
dans l'orge ont réflété une combinaison du déplacement de l'air par le $\mathrm{CO}_{2}$ et de l'utilisation $\mathrm{d}^{\prime} \mathrm{O}_{2}$ pour la respiration des grains et des microorganismes aux températures plus élevées. Les insectes Cryptolestes ferrugineus et Tribolium castaneum ont été réprimés en 2 semaines à $34 \%$ de $\mathrm{CO}_{2}$ et $15 \%$ d' $\mathrm{O}_{2}$ à une température passant de 18 à $10^{\circ} \mathrm{C}$, ou à $29 \%$ de $\mathrm{CO}_{2}$ et $3 \%$ d' $\mathrm{O}_{2}$ à une température passant de 25 à $20^{\circ} \mathrm{C}$. Les acariens Tarsonemus granarius, Lepidoglyphus destructor et Aeroglyphus robustus ont été réprimés en moins de 2 semaines à ces concentrations de $\mathrm{CO}_{2}$. La germination des grains et la microflore n'ont pas été affectées par tous ces environnements gazeux.

\section{INTRODUCTION}

Controlled atmospheres with high levels of carbon dioxide $\left(\mathrm{CO}_{2}\right)$, or nitrogen $\left(\mathrm{N}_{2}\right)$ and low levels of oxygen $\left(\mathrm{O}_{2}\right)$ are effective for controlling insects and mites in stored grain (Jayas et al. 1991). The toxicity of $\mathrm{CO}_{2}$ and $\mathrm{N}_{2}$ is dependent on temperature and relative humidity. Longer exposures to these gases than to synthetic neurotoxic fumigants are required to kill pests (Annis 1986). Currently, methyl bromide and phosphine gas are the only fumigants used on stored products in North America. These fumigants may leave chemical residues in stored food and chemically react with structural materials (Bond 1984). Phosphine is a potential mutagen in humans (Garry et al. 1989; Potter et al. 1991), and methyl bromide can decrease seed germination and reacts intensely with atmospheric ozone. Resistance to fumigants by insects is slowly increasing throughout the world (Taylor 1989). Methyl bromide and phosphine are currently under regulatory review in the United States and methyl bromide is being phased out in Canada. The possibility of losing these fumigants in Canada could result in $\$ 20-\$ 160$ million losses annually because of the effects of pest infestation on grain quantity and quality (Waithe 1991). Alternate methods, such as controlled atmospheres, could be used to prevent these losses.

Carbon dioxide is a more effective gas than nitrogen in a controlled atmosphere, because virtual elimination of oxygen is not necessary with $\mathrm{CO}_{2}$. Carbon dioxide also causes desiccation of insects when spiracles are opened and causes direct physiological action rather than simple suffocation (Nicholas and Sillans 1989). The utility and efficacy of $\mathrm{CO}_{2}$ applied as both compressed gas and solid (dry ice) has been studied in the past (Jay 1980; Jay and D'Orazio 1984).

Carbon dioxide, which is registered for fumigation of stored cereals in Canada, does not leave chemical residues in food, is less likely to produce highly resistant insects, and can be economical (White and Jayas 1991). Prolonged controlled atmosphere storage may also control fungal growth and does not reduce germination of stored grain (White and Jayas 1993).

A major limitation to using $\mathrm{CO}_{2}$ on farms is that most storage bins are not air-tight. Attempts can be made to seal storage structures and to increase bin air-tightness to minimize gas loss (Banks and Annis 1980). Controlled atmospheres also can be made practical by modifying storage atmospheres by a series of gas infusions or a continuous gas flow to obtain required gas concentrations and gradients predicted with computer models (White et al. 1993). The most costefficient and effective method of fumigation, however, is with air-tight bins.

Several species of insects and mites typically occur together in farm-stored grain in western Canada (Madrid et al. 1990; White and Sinha 1990). Responses to controlled atmospheres vary among species (Jay 1984; Krishnamurthy et al. 1986). Grain temperatures rarely exceed $20^{\circ} \mathrm{C}$ in the centre of 5-m-diam bins within several months of harvest in western Canada (Sinha and Wallace 1977) unless active spoilage is occurring. The low temperatures slow the effectiveness of all toxic gases because of the lowered metabolism of insects and mites. The zero tolerance for detectable insects in Canadian grain makes disinfestation at cool temperatures a concern. It is necessary 
to determine a practical technique for generating $\mathrm{CO}_{2}$ and the levels and exposure times for effective pest control under simulated conditions. The aim of this study was to determine the effectiveness of injected or sublimated $\mathrm{CO}_{2}$ on control of insects and mites frequently found in western Canada at typical autumn temperatures of stored grain which can be harvested warm $\left(>30^{\circ} \mathrm{C}\right)$ but will gradually cool.

\section{MATERIALS AND METHODS}

\section{Storage bins}

Fifteen cylindrical steel bins $(444 \mathrm{~L}, 58 \mathrm{~cm}$ diam $\times 168 \mathrm{~cm}$ high) were each constructed by welding two steel oil drums together end to end. A removable lid was attached to the top of the bins with a circular band of steel and a bolt tightener. The bins were placed on 20-cm-high concrete blocks. Six equally spaced grain and gas sampling ports were made in a spiral pattern along the vertical sides of the bins, with an additional sampling port in the centre of the bottom (White et al. 1990). A copper-constantan thermocouple was positioned beside each gas sampling tube.

\section{Grain storage}

Injected $\mathrm{CO}_{2}$ - wheat

Each bin was filled with $322 \mathrm{~kg}(431 \mathrm{~L})$ of Canada western red spring wheat (Triticum aestivum L.) with a $15-16 \%$ moisture content and containing $\approx 0.8 \%$, by weight, dockage (chaff, broken kernels).

One thousand adults of both the rusty grain beetle, Cryptolestes ferrugineus (Stephens) [Coleoptera: Cucujidae], and the red flour beetle, Tribolium castaneum (Herbst) [Coleoptera: Tenebrionidae], were added to the tops of all bins with ventilation holes $16 \mathrm{~cm}$ in diam covered with wire mesh) in the lids and left for 5 wk at $30^{\circ} \mathrm{C}$ to multiply. The mites Tarsonemus granarius Lindquist [Acarina: Tarsonemidae], Aeroglyphus robustus (Banks) [Acarina: Glycyphagidae], Lepidoglyphus destructor (Schrank) [Acarina: Glycyphagidae], and some Tydeidae spp. also were naturally present in low numbers. All treatments were replicated three times. The five treatments were: bins that remained as open con- trols, bins tightly sealed but with no $\mathrm{CO}_{2}$ added, bins each receiving $2 \mathrm{~min}$ of gas flow $\left(25 \% \mathrm{CO}_{2}\right.$ treatment), bins each receiving 4 min of gas flow $\left(34 \% \mathrm{CO}_{2}\right.$ treatment), and bins each receiving $6 \mathrm{~min}^{2}$ of gas flow ( $46 \% \mathrm{CO}_{2}$ treatment). The $\mathrm{CO}_{2}$ was obtained from a compressed-gas cylinder holding $22.7 \mathrm{~kg}$ of $\mathrm{CO}_{2}$ and introduced at a rate of $40 \mathrm{~L} \mathrm{~min}^{-1}$ through the bottom gas-sampling port. The top port was temporarily opened to permit pressure equalization. Temperatures in the storage room gradually declined from 18 to $10^{\circ} \mathrm{C}$ during the 12 -wk study.

Gas and grain samples as well as temperatures were taken from seven vertically-arranged sample locations per bin initially and then bi-weekly for $12 \mathrm{wk}$ ( 7 samples per bin; 21 samples $(200 \mathrm{~mL}$ of grain) per treatment $\times 5$ treatments $=105$ samples per date).

\section{Dry lce $\left(\mathrm{CO}_{2}\right)$ - barley}

The same 15 bins were later emptied, thoroughly cleaned and refilled with barley (Hordeum vulgare L.) at $15 \%$ moisture content. One thousand adults of $C$. ferrugineus and $T$. castaneum, and several thousand adults of the mite $A$. robustus were added to each bin and allowed to multiply for 5 wk at $30^{\circ} \mathrm{C}$ in bins which all had ventilated lids. The mite $L$. destructor was also naturally present in the grain. The treatments were: bins that remained open, bins sealed tightly but with no $\mathrm{CO}_{2}$ added, bins each receiving $96 \mathrm{~g}$ of dry ice as pellets $\left(\approx 30 \% \mathrm{CO}_{2}\right)$, bins each receiving $128 \mathrm{~g}$ dry ice $\left(\approx 40 \% \mathrm{CO}_{2}\right)$ and bins each receiving $160 \mathrm{~g}$ dry ice $\left(\approx 50 \% \mathrm{CO}_{2}\right)$. All treatments were replicated three times. The dry ice was added to the top of the grain bulks and a bottom grain-sampling septum was removed until gas pressure in the drums equalled atmospheric pressure. The experiment was conducted at temperatures gradually declining from 25 to $20^{\circ} \mathrm{C}$ over an 8-wk period. Gas and grain samples as well as temperatures were taken at the top, middle, and bottom of each bin initially and then once a week for $8 w k$, with the exception of week 7 (3 samples per bin; 9 samples per treatment $\times 5$ treatments $=45$ samples per week).

\section{Sampling procedures}

Methods for monitoring variables, sam- 
WHEAT - INJECTED $\mathrm{CO}_{2}$
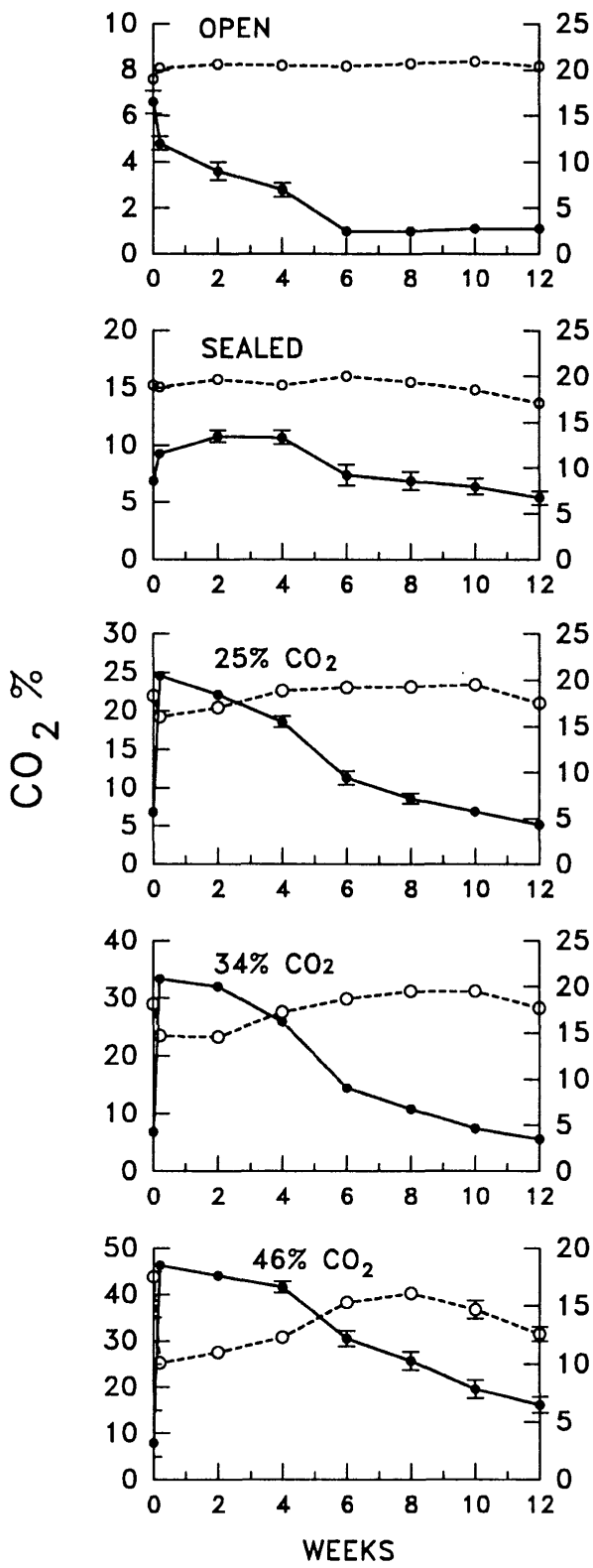

BARLEY - DRY ICE
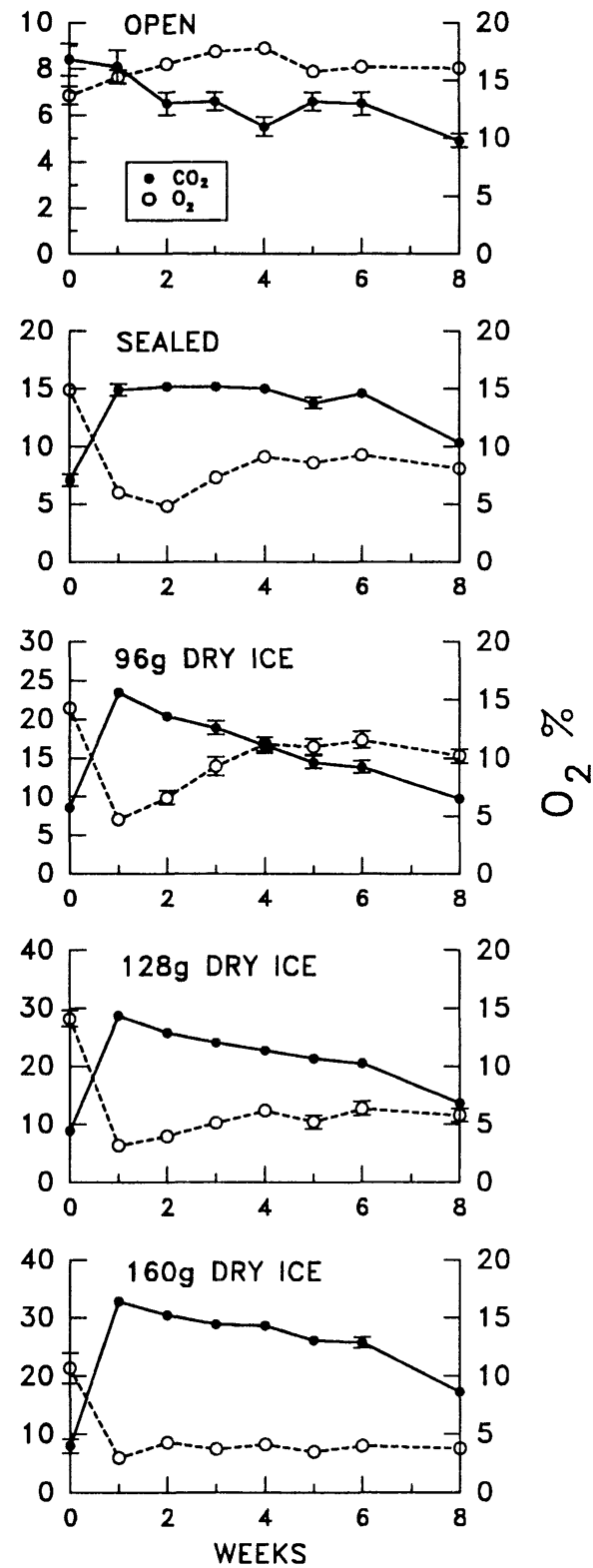

Figure 1. Mean $( \pm S E)$ of $\mathrm{CO}_{2}$ and $\mathrm{O}_{2}$ levels of wheat in bins with open lids, sealed lids, or treated with compressed $\mathrm{CO}_{2}(25 \%, 34 \%$ or $46 \%)(n=7$ locations per bin, 3 bins per treatment); and mean $( \pm \mathrm{SE}) \mathrm{CO}_{2}$ and $\mathrm{O}$, levels of barley in bins with open lids, sealed lids, or treated with 96 g $\left(23 \% \mathrm{CO}_{2}\right), 128 \mathrm{~g}\left(29 \% \mathrm{CO}_{2}\right)$, or $160 \mathrm{~g}\left(34 \% \mathrm{CO}_{2}\right)$ dry ice $(n=3$ locations per bin, 3 bins per treatment). 
pling procedures, and grain sample analyses were previously reported (White et al. 1990). The variables monitored included $\mathrm{CO}_{2}$ and $\mathrm{O}_{2}$ (gas chromatography; Matheson gas chromatograph,-model $8430,1 \mathrm{~mL}$ fixed volume sample loops, thermal conductivity detector), temperature (thermocouples, potentiometer), grain moisture content (oven-dry methodology, $130^{\circ} \mathrm{C}$ for $19 \mathrm{~h}$ ), numbers of insects and mites per $150 \mathrm{~mL}$ grain sample (Berlese funnel extraction), and seed germination and microfloral infection at the beginning and end of the study (incubation at $22^{\circ} \mathrm{C}$ on watersaturated or $\mathrm{NaCl}$ solution-saturated filter papers). All data were summarized and analyzed (ANOVA) using SAS procedure GLM (SAS Institute 1985).

\section{RESULTS AND DISCUSSION}

\section{Injected $\mathrm{CO}_{2}$ - wheat}

Moisture content of the wheat did not change during the study, but there were significant differences $(P \leq 0.01)$ in moisture content between locations in bins and treatments. Wheat was drier at top than at bottom locations of the bins and grain in the open bins was drier than all other treatments. Means and standard errors for moisture contents of grain at top and bottom locations were $14.5 \pm 0.1$ and $15.9 \pm 0.2$ for open bins, $15.3 \pm 0.1$ and $16.3 \pm 0.1$ for sealed bins, $15.8 \pm 0.2$ and $16.3 \pm 0.1$ for $25 \% \mathrm{CO}_{2}$ treatment, $15.3 \pm 0.2$ and $16.3 \pm 0.1$ for $34 \% \mathrm{CO}_{2}$ treatment, and $15.5 \pm 0.1$ and $16.3 \pm 0.1 \%$ for $46 \% \mathrm{CO}_{2}$ treatment.

Carbon dioxide levels were near $5 \%$ at the beginning of the study (Fig. 1) because of insect, microflora, and grain respiration after $5 \mathrm{wk}$ incubation at $30^{\circ} \mathrm{C}$ (White et al. 1982). There were significant differences $(P \leq 0.01)$ in both $\mathrm{CO}_{2}$ and $\mathrm{O}_{2}$ levels with time (bin leakage) among locations within bins and among treatments. There was usually $1-3 \%$ more $\mathrm{CO}_{2}$ at bin bottoms than tops, because $\mathrm{CO}_{2}$ density is greater than that of air.

The mean gas levels from all samples in a treatment showed that $\mathrm{CO}_{2}$ declined from about $5 \%$ to $1 \%$ in the open bins after $12 \mathrm{wk}$ (ambient air levels are $0.03 \%$ $\mathrm{CO}_{2}$ ) and $\mathrm{O}_{2}$ levels remained near ambient-air levels of $20.9 \%$ by volume (Fig. 1). The sealed bins had $\mathrm{CO}_{2}$ levels near $11 \%$ by the second week, declining to $5 \%$ after 12 wk with $\mathrm{O}_{2}$ levels usually near $19 \%$. The initial 25,34 , and $46 \% \mathrm{CO}_{2}$ treatments had corresponding $\mathrm{O}_{2}$ levels of 16,15 , and $10 \%$ (Fig. 1) at the beginning of the experiment. The $\mathrm{CO}_{2}$ levels declined by 80,85 , and $65 \%$ from initial values after $12 \mathrm{wk}$ for the 25,34 , and $46 \%$ $\mathrm{CO}_{2}$ treatments, respectively, because of gas loss during grain sampling.

At time 0 there were between 2 and 22 adults, and 2.5 and 10 larvae of $C$. ferrugineus in $150 \mathrm{~mL}$ of wheat from the various treatments (Fig. 2). The total numbers of adults and larvae per bin did not change appreciably over $12 \mathrm{wk}$ in the open bins or the sealed bins because the cool temperatures inhibited reproduction and development (Sinha and Watters 1985). However, the mean number of $C$. ferrugineus adults per sample increased sharply at $6 \mathrm{wk}$ because most of the adults in the bins moved to the bottom sample of the sealed bins without added $\mathrm{CO}_{2}$ as compared to previous even distribution throughout the grain bulk (White and Jayas 1991) (Fig. 2). Larvae are much less mobile and tend to stay inside the germ of seeds so their distribution did not change. Virtually all adults and larvae were killed in 2 to $4 \mathrm{wk}$ in all $\mathrm{CO}_{2}$ treatments including the lowest $\mathrm{CO}_{2}$ treatment which had $\mathrm{CO}_{2}$ concentration declining from 25 to $18 \%$, and $\mathrm{O}_{2}$ concentration rising from 16 to $19 \%$. $A^{2}$ few $T$. castaneum adults and larvae survived 12 wk even at the highest $\mathrm{CO}_{2}$ level (46\% declining to $16 \% \mathrm{CO}_{2}$ ) (Fig. 3). Throughout the study, $C$. ferrugineus adults and larvae were more common in lower regions of the bins, while $T$. castaneum adults and larvae were more common near the upper levels of the bins. There were $0.4 \pm 0.3 \mathrm{~T}$. granarius, $25 \pm 10$ Tydeidae ., $0.1 \pm 0.1$ L. destructor, and $0.2 \pm 0.1 A$. robustus per $150 \mathrm{~mL}$ wheat at the beginning of the study. By the second week, all mites were absent from treatments with injected $\mathrm{CO}_{2}$, but at $12 \mathrm{wk}$, there were $50.7 \pm 25.2$ and $18.5 \pm 6.6 \mathrm{~T}$. granarius and $0.7 \pm 0.5$ and $1.4 \pm 1.0 \mathrm{~A}$. robustus per sample in the open bins and the sealed bins, respectively. 

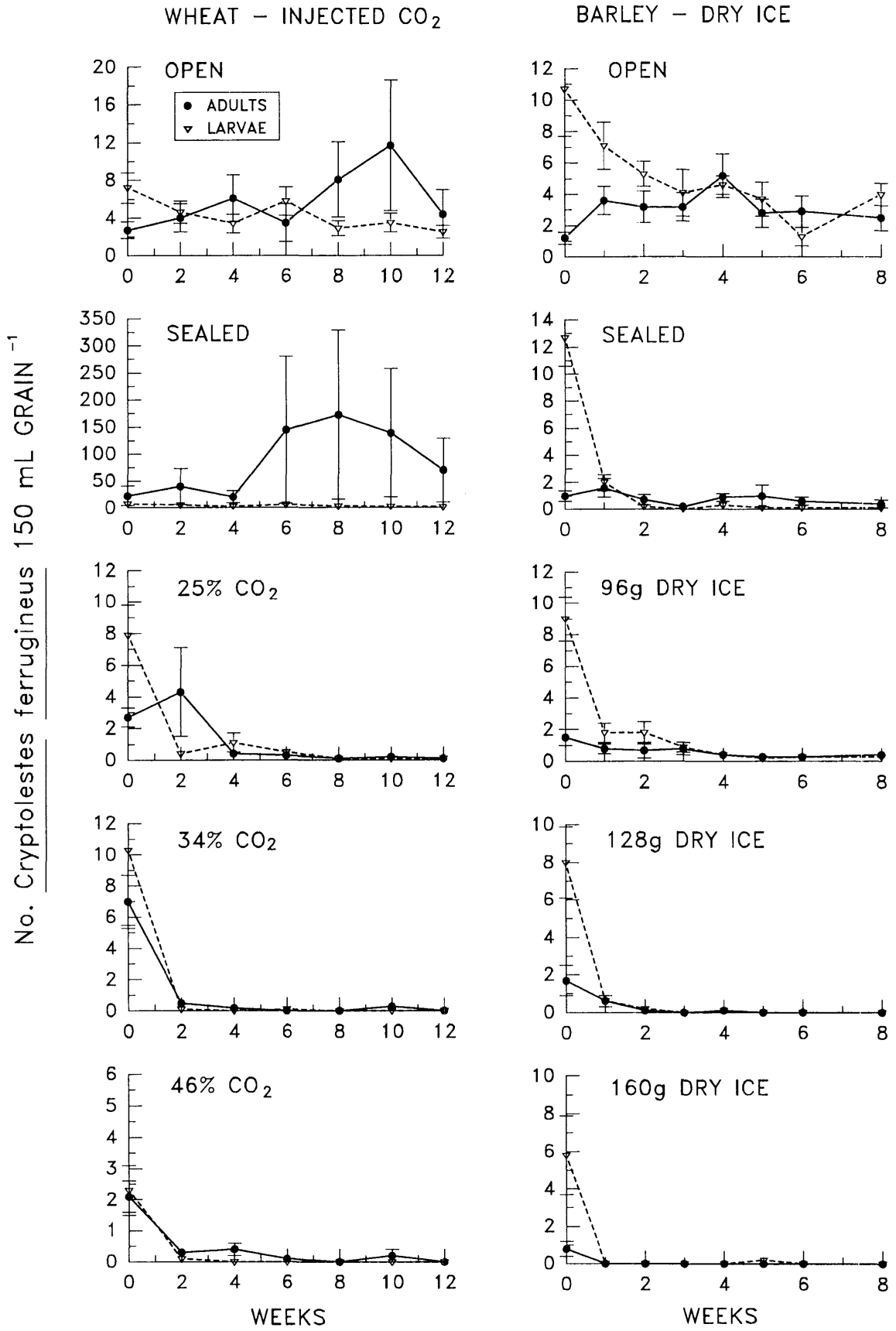

Figure 2. Mean ( \pm SE) numbers of Cryptolestes ferrugineus adults and larvae per $150 \mathrm{~mL}$ of wheat in bins with ventilated lids, sealed lids, or treated with compressed $\mathrm{CO}_{2} 125 \%$, $34 \%$ or $46 \%)(n=7$ locations per bin, 3 bins per treatment); and mean ( $\pm S E$ ) numbers of C. ferrugineus adults and larvae per $150 \mathrm{~mL}$ barley in bins with open lids, sealed licls, or treated with $96 \mathrm{~g}\left(23 \% \mathrm{CO}_{2}\right), 128 \mathrm{~g}\left(29 \% \mathrm{CO}_{2}\right)$, or $160 \mathrm{~g}\left(34 \% \mathrm{CO}_{2}\right)$ dry ice ( $n=3$ locations per bin, 3 bins per treatment). 
Germination of all wheat seeds was very low at the beginning of the study because of prolonged storage at warm temperatures prior to obtaining the grain. It did not change significantly during the 12-wk period (Table 1). Infection by fungi, Penicillium spp., remained relatively low and did not change significantly over 12 wk (Table 1). Aspergillus glaucus group fungi were common, initially infecting $70-92 \%$ of seeds (Table 1) and the frequency of infection declined over $12 \mathrm{wk}$.

\section{Dry ice $\left(\mathrm{CO}_{2}\right)$ - barley}

Moisture content of the barley did not change during the study. The top of the grain in the open bins was significantly $(P \leq 0.01)$ drier than in other treatments. Means and standard errors for moisture contents of grain at top and bottom locations were $14.5 \pm 0.4$ and $14.9 \pm 0.3$ for open bins, $15.4 \pm 0.1$ and $14.8 \pm 0.1$ for sealed bins, $15.4 \pm 0.1$ and $14.8 \pm 0.1$ for 96-g dry ice bins, $15.2 \pm 0.1$ and $15.5 \pm 0.6$ for 128-g dry ice bins, and $15.3 \pm 0.1$ and $16.1 \pm 0.3 \%$ for $160-g$ dry ice bins.

Carbon dioxide levels following $5 \mathrm{wk}$ of insect incubation at $30^{\circ} \mathrm{C}$ and prior to adding $\mathrm{CO}_{2}$, were near $8 \%$ because of intense insect, microflora, and grain res- piration (Fig. 1). Once the experiment began at $25^{\circ} \mathrm{C}, \mathrm{CO}_{2}$ gradually declined to about $5 \%$ and $\mathrm{O}_{2}$ increased to about $16 \%$ by week 8 in the open bins (Fig. 1). In the sealed bins, mean $\mathrm{CO}_{2}$ levels rose to about $15 \%$ and remained at that level until week 6. Oxygen levels fell as low as $5 \%$ reflecting hermetic storage conditions for relatively moist grain at warm temperatures (Penteado et al. 1990). There were significant differences $(P \leq 0.01)$ in both $\mathrm{CO}_{2}$ and $\mathrm{O}_{2}$ level changes with time (bin leakage), among locations within the bins (1-3\% more $\mathrm{CO}_{2}$ at bin bottoms than tops), and among treatments. The addition of dry ice did not change grain temperatures. Calculated $\mathrm{CO}_{2}$ levels were 30,40 , and $50 \%$; actual mean $\mathrm{CO}_{2}$ levels were 23,29 , and $34 \%$, corresponding to 77,73 , and $68 \%$ of the calculated levels, respectively. The lower levels were probably caused by gas adsorption by the grain (Cofie-Agblor et al. 1993) and gas pressure increase in the bin which resulted in forced air movement while the bins were vented during gas introduction.

The $\mathrm{O}_{2}$ levels in the dry ice treatments were lower than would be caused by displacement of air with $\mathrm{CO}_{2}$ and resulted from a combination of $\mathrm{CO}_{2}^{2}$ introduction

Table 1. Initial and final ( $\bar{X} \pm S E$ ) seed germination and frequency of microfloral infection of seeds in wheat stored at temperatures decreasing from 18 to $10^{\circ} \mathrm{C}$ under various $\mathrm{CO}_{2}$ enriched atmospheres for 12 wk $^{\mathrm{a}}$

\begin{tabular}{|c|c|c|c|c|c|}
\hline \multirow[b]{2}{*}{ Treatment } & \multirow[b]{2}{*}{$\begin{array}{c}\mathrm{CO}_{2}: \mathrm{O}_{2} \\
\text { concentration at } 1 \mathrm{~h} \\
(\%)\end{array}$} & \multirow[b]{2}{*}{$\begin{array}{l}\text { Storage } \\
\text { period } \\
(w k)\end{array}$} & \multirow[b]{2}{*}{$\begin{array}{c}\text { Seed } \\
\text { germination } \\
(\%)\end{array}$} & \multicolumn{2}{|c|}{ Frequency of seed infection } \\
\hline & & & & $\begin{array}{c}\text { Aspergillus } \\
\text { glaucus group } \\
(\%)\end{array}$ & $\begin{array}{c}\text { Penicillium } \\
\text { spp. } \\
(\%)\end{array}$ \\
\hline \multirow[t]{2}{*}{ Open bin } & $4.8: 20$ & 0 & $5.0 \pm 3.9$ & $86.1 \pm 2.7$ & $9.7 \pm 1.8$ \\
\hline & & 12 & $3.4 \pm 2.0$ & $73.8 \pm 4.8$ & $7.2 \pm 1.6$ \\
\hline \multirow[t]{2}{*}{ Sealed bin } & $9: 19$ & 0 & $1.5 \pm 0.5$ & $85.9 \pm 2.6$ & $7.0 \pm 1.3$ \\
\hline & & 12 & 0 & $70.4 \pm 6.3$ & $4.6 \pm 2.0$ \\
\hline \multirow[t]{2}{*}{$24 \% \mathrm{CO}_{2}$ bin } & $24: 16$ & 0 & 0 & $69.9 \pm 4.1$ & $27.9 \pm 3.6$ \\
\hline & & 12 & $0.1 \pm 0.1$ & $58.0 \pm 4.5$ & $17.4 \pm 3.4$ \\
\hline \multirow[t]{2}{*}{$34 \% \mathrm{CO}_{2}$ bin } & $34: 15$ & 0 & $3.8 \pm 1.3$ & $91.8 \pm 2.2$ & $5.1 \pm 1.1$ \\
\hline & & 12 & $6.3 \pm 2.3$ & $74.5 \pm 3.6$ & $7.6 \pm 1.6$ \\
\hline \multirow[t]{2}{*}{$46 \% \mathrm{CO}_{2}$ bin } & $46: 10$ & 0 & $2.9 \pm 1.3$ & $89.6 \pm 2.2$ & $12.3 \pm 2.2$ \\
\hline & & 12 & $2.3 \pm 0.8$ & $68.0 \pm 4.0$ & $9.1 \pm 2.8$ \\
\hline
\end{tabular}

${ }^{a} \mathrm{n}=21$ sample locations per treatment, 7 samples per bin; 25 seeds per location.

$\mathrm{CO}_{2}$ was added as compressed gas. 

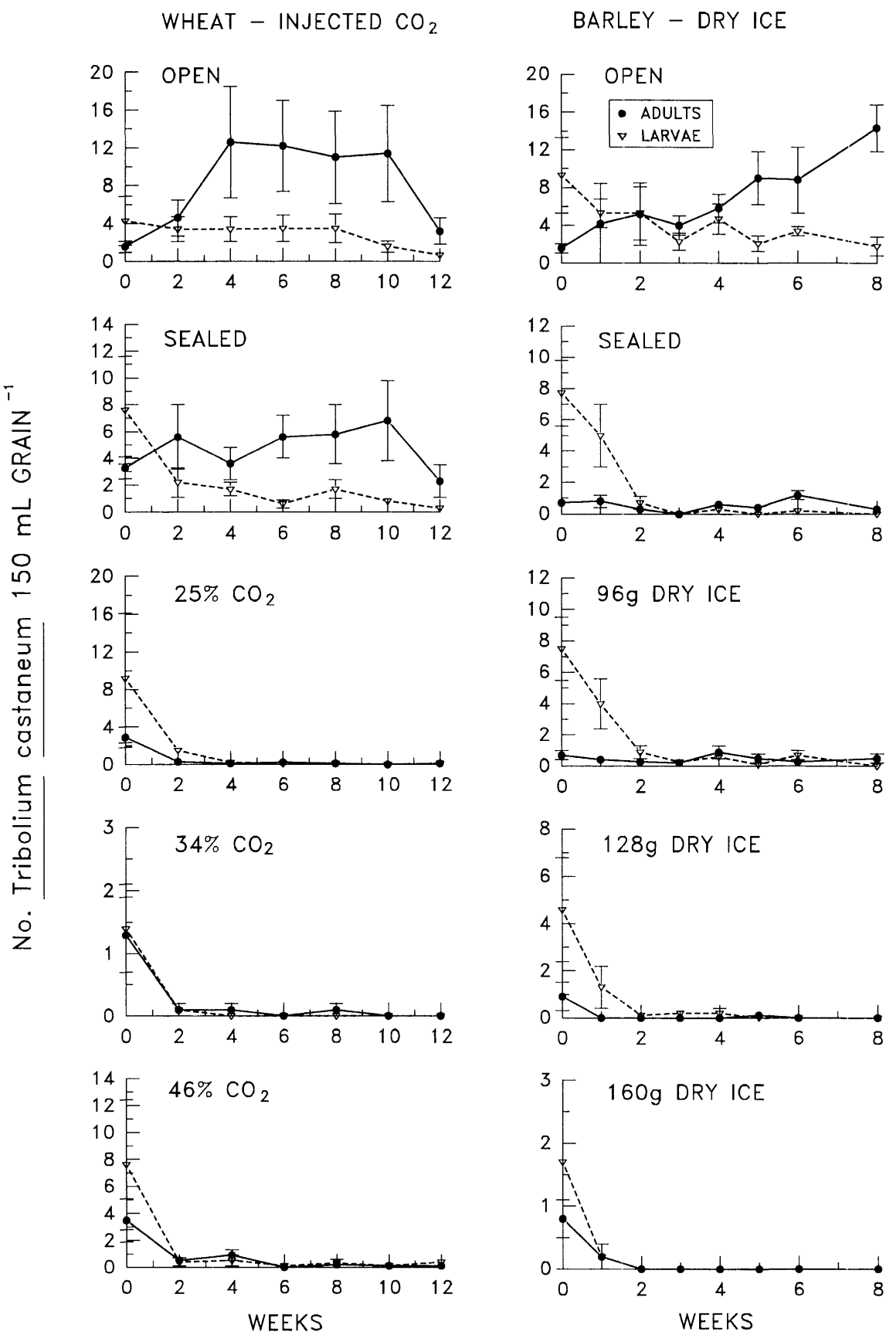

Figure 3. Mean ( \pm SE) numbers of Tribolium castaneum adults and larvae per $150 \mathrm{~mL}$ of wheat in bins with open lids, sealed lids, or treated with compressed $\mathrm{CO}_{2}(25 \%, 34 \%$ or $46 \%$ ) ( $n=7$ locations per bin, 3 bins per treatment); and mean ( \pm SE) numbers of $T$. castaneum adults and larvae per $150 \mathrm{~mL}$ barley in bins with open lids, sealed lids, or treated with $96 \mathrm{~g}\left(23 \% \mathrm{CO}_{2}\right), 128 \mathrm{~g}\left(29 \% \mathrm{CO}_{2}\right)$, or $160 \mathrm{~g}\left(34 \% \mathrm{CO}_{2}\right)$ dry ice ( $n=3$ locations per bin, 3 bins per treatment). 
and remaining $\mathrm{O}_{2}$ consumption by respiring grain and microorganisms at warm temperatures (White et al. 1982).

At time 0 , there was a mean of one adult and 6-13 larvae of $C$. ferrugineus per $150 \mathrm{~mL}$ of barley as well as one adult and 2-9 larvae of $T$. castaneum (Figs. 2 and 3 ). In the open bins, the number of C. ferrugineus adults remained fairly constant for $8 \mathrm{wk}$ and the numbers of larvae gradually declined (Fig. 2). The number of $T$. castaneum adults rose to over 14 per $150 \mathrm{~mL}$ barley at week 8 , while larval numbers decreased. The sealed bins offered good insect regulation in $3 \mathrm{wk}$ which was equivalent to the 96-g dry ice treatment (Figs. 2 and 3). Insects were controlled in the sealed bins more effectively than in the wheat experiment sealed bins because temperatures in the barley were warmer and there was more $\mathrm{CO}_{2}$. The 128-g dry ice treatment $\left(29 \% \mathrm{CO}_{2}, 3 \% \mathrm{O}_{2}\right)$ eliminated most insects in 2 wk although a few T. castaneum adults survived for 5 wk (Figs. 2 and 3). The 160-g dry ice treatment $(34 \%$ $\mathrm{CO}_{2}, 3 \% \mathrm{O}_{2}$ ) eliminated $\mathrm{C}$. ferrugineus in $1 \mathrm{wk}$ and T. castaneum in $2 \mathrm{wk}$ (Figs. 2 and 3).
As in the earlier study using wheat, C. ferrugineus were more numerous in the lower half of the grain columns and $T$. castaneum were more numerous in the top half of the grain columns throughout the experiments. At week 0 , no $L$. destructor were noted in grain samples, but there were $22 \pm 6 A$. robustus per $150 \mathrm{~mL}$ of barley. At $8 \mathrm{wk}$, in the open bins, there were $33 \pm 15 \mathrm{~L}$. destructor and $21 \pm 11$ A. robustus per $150 \mathrm{~mL}$ barley. A few $L$. destructor survived in top samples of the sealed bins at $8 \mathrm{wk}(0.3 \pm 0.2$ per $150 \mathrm{~mL}$ barley), but $A$. robustus did not survive more than $4 \mathrm{wk}$. The occasional L. destructor or A. ro-bustus were detected for up to $8 \mathrm{wk}$ in the $96 \mathrm{~g}$ dry ice treatment. The two higher $\mathrm{CO}_{2}$ treatments had no mites after 1 wk.

Germination of all seeds was initially between 88 and $93 \%$ after 8 wk declined significantly $(P \leq 0,5)$ only in the open bins (Table 2) where insects were most common. There were no significant changes in Penicillium $1<3 \%$ of the seeds infected) or $A$. glaucus group infections in any treatment during 8-wk period (Table 2).

Table 2. Initial and final $(\bar{X} \pm S E)$ seed germination and frequency of microfloral infection of seeds in barley stored at temperatures declining from 25 to $20^{\circ} \mathrm{C}$ under various $\mathrm{CO}_{2}$ enriched atmospheres for $8 w^{a}$

\begin{tabular}{lccccc}
\hline & & & \multicolumn{2}{c}{ Frequency of seed infection } \\
\cline { 5 - 6 } Treatment & $\begin{array}{c}\mathrm{CO}_{2}: \mathrm{O}_{2} \\
\text { concentration at } 1 \mathrm{~h} \\
(\%)\end{array}$ & $\begin{array}{c}\text { Storage } \\
\text { period } \\
(\mathrm{wk})\end{array}$ & $\begin{array}{c}\text { Seed } \\
\text { germination } \\
(\%)\end{array}$ & $\begin{array}{c}\text { Aspergillus } \\
\text { glaucus group } \\
(\%)\end{array}$ & $\begin{array}{c}\text { Penicillium } \\
\text { spp. } \\
(\%)\end{array}$ \\
\hline Open bin & $8.5: 15$ & 0 & $88.2 \pm 2.2$ & $51.1 \pm 5.5$ & $0.7 \pm 0.3$ \\
& & 8 & $81.8 \pm 2.0$ & $55.4 \pm 8.9$ & $0.9 \pm 0.5$ \\
Sealed bin & $15: 6$ & 0 & $90.7 \pm 0.8$ & $50.7 \pm 5.6$ & $2.0 \pm 0.7$ \\
& & 8 & $84.9 \pm 2.9$ & $61.8 \pm 7.7$ & $3.0 \pm 0.9$ \\
$96 \mathrm{~g} \mathrm{bin}^{-1}$ & $23: 5$ & 0 & $93.0 \pm 1.1$ & $60.5 \pm 6.5$ & $2.0 \pm 0.6$ \\
& $29: 3$ & 8 & $90.7 \pm 1.6$ & $47.7 \pm 5.0$ & $1.7 \pm 0.8$ \\
$128 \mathrm{~g} \mathrm{bin}^{-1}$ & & 0 & $89.3 \pm 2.2$ & $46.4 \pm 6.4$ & $0.9 \pm 0.5$ \\
& $34: 3$ & 8 & $89.3 \pm 1.8$ & $54.2 \pm 7.2$ & $0.9 \pm 0.6$ \\
$160 \mathrm{~g} \mathrm{bin}^{-1}$ & & 0 & $90.0 \pm 1.3$ & $47.0 \pm 6.1$ & $0.3 \pm 0.3$ \\
& & 8 & $90.7 \pm 2.7$ & $52.3 \pm 9.4$ & $2.0 \pm 0.9$ \\
\hline
\end{tabular}

${ }^{a} \mathrm{n}=9$ sample locations per treatment, 3 samples per bin; 50 seeds per location.

$\mathrm{CO}_{2}$ was added as dry ice. 
Based on the range of $\mathrm{CO}_{2}$ levels tested, this study indicated that moderate levels of $\mathrm{CO}_{2}\left(34 \% \mathrm{CO}_{2}\right.$ and $15 \% \mathrm{O}_{2}$ at temperatures decreasing from 18 to $10^{\circ} \mathrm{C}$, or $29 \% \mathrm{CO}_{2}$ and $3 \% \mathrm{O}_{2}$ with temperature decreasing from 25 to $20^{\circ} \mathrm{C}$ ) were very effective in controlling insects and mites in wheat and barley in relatively air-tight bins in $2 \mathrm{wk}$. Lower levels of $\mathrm{CO}_{2}$ are adequate for insect control if longer exposure is maintained while higher temperatures could increase the rate of the toxic action of the gas (White et al. 1988).

While solid $\mathrm{CO}_{2}$ is often more convenient to handle and to weigh accurate quantities of gas applied to grain, it is considerably more expensive than compressed $\mathrm{CO}_{2}$. Regardless of the formulation, care must be taken in generating desired gas levels because of gas adsorption by grain (Banks 1993; CofieAgblor et al. 1993). It is impractical to make most farm granaries airtight, but if efforts are made to reduce gas loss, such as by placing plastic sheets impermeable to $\mathrm{CO}_{2}$ over the grain bulk surface and caulking bin walls, it should be possible to control arthropod infestations. Carbon dioxide would be most effective in welded steel hopper bins, hopper railcars, or in polyethylene temporary grain bins, which are used in years of large harvests.

\section{ACKNOWLEDGEMENTS}

We thank the Natural Sciences and Engineering Research Council of Canada for partial funding of this study as well as $\mathrm{G}$. Gerber and P. Barker of the Winnipeg Research Station for reviewing this manuscript.

\section{REFERENCES}

Annis, P.C. 1986. Towards rational controlled atmosphere dosage schedules: a review of current knowledge. Pages 128-148 in $\mathrm{E}$. Donahaye and S. Navarro (eds.), Proceedings 4th International Working Conference on Stored-Product Protection, Tel Aviv, Israel, Maor-Wallach, Jerusalem.
Banks, H.J. 1993. Factors governing sorption and desorption of fumigants on grain. In S. Navarro and E. Donahaye (eds.), Proceedings International Conference on Controlled Atmosphere and Fumigation in Grain Storage (in press).

Banks, H.J., and P.C. Annis. 1980. Conversion of existing grain storage structures for modified atmosphere use. Pages 461-473 in J. Shejbal (ed.), Controlled atmosphere storage of grains, Elsevier Science Publ., Amsterdam, Netherlands.

Bond, E.J. 1984. Manual of fumigation for insect control. FAO Plant Prod. Prot. Publ. 54. $432 \mathrm{pp}$.

Cofie-Agblor, R., W.E. Muir, and D. Jayas. 1993. Carbon dioxide gas sorption in stored wheat. In S. Navarro and E. Donahaye (eds.), Proceedings International Conference on Controlled Atmosphere and Fumigation in Grain Storage (in press).

Garry, V.F., J. Griffith, T.J. Danyl, R.L. Nelson, E.B. Whorton, L.A. Krueger, and J. Gervenka. 1989. Human genetoxicity, pesticide applicators and phosphine. Science 246: 251-255.

Jay, E.G. 1980. Methods of applying carbon dioxide for insect control in stored grain. USDA, SEA, Adv. Agric. Technol., South. Ser., S-13. $7 \mathrm{pp}$.

Jay, E. 1984. Imperfections in our current knowledge of insect biology as related to their response to controlled atmospheres. Pages 493-508 in B.E. Ripp (ed.), Controlled atmosphere and fumigation in grain storages. Elsevier, Amsterdam.

Jay, E., and R. D'Orazio. 1984. Progress in the use of controlled atmospheres in actual field situations in the United States. Pages 3-14 in B.E. Ripp (ed.), Controlled atmosphere and fumigation in grain storages. Elsevier, Amsterdam.

Jayas, D.S., B. Khangura, and N.D.G. White. 1991. Controlled atmosphere storage of grains. Postharvest News Info. 2: 423-427.

Krishnamurthy, T.S., E.C. Spratt, and C.H. Bell. 1986. The toxicity of carbon dioxide to adult beetles in low oxygen atmospheres. J. Stored Prod. Res. 22: 145-151.

Madrid, F.J., N.D.G. White, and S.R. Loschiavo. 1990. Insects in stored cereals, and their association with farming practices in southern Manitoba. Can. Entomol. 122: 515523.

Nicholas, G., and D. Sillans. 1989. Immediate and latent effects of carbon dioxide on insects. Annu. Rev. Entomol. 34: 97-116.

Penteado, M.F.P., M.R. Sartori, P. Vitti, E.E.M. Mori, and P.R.N. Carvalho. 1990. Quality of paddy stored in underground silos. Part I. Pages 901-910 in F. Fleurat-Lessard and P. Ducom (eds.), Proceedings 5th International Working Conference on Stored product Protection, Vol. II. Bordeaux, France. 
Potter, W.T., S. Rong, J. Griffith, J. White, and V.F. Garry. 1991. Phosphine-mediated Heing body formation and hemoglobin oxidation in human erythrocytes. Toxicol. Lett. 57: 37-45.

SAS Institute. 1985. SAS User's Guide: Statistics. SAS Institute, Cary, NC. 956 pp.

Sinha, R.N., and H.A.H. Wallace. 1977. Storage stability of farm-stored rapeseed and barley. Can. J. Plant Sci. 57: 351-365.

Sinha, R.N., and F.L. Watters. 1985. Insect pests of flour mills, grain elevators, and feed mills and their control. Agric. Can. Publ. 1776, Ottawa, Ont. 290 pp.

Taylor, R.W.D. 1989. Phosphine - a major grain fumigant at risk. Int. Pest Control 31: 10-14.

Waithe, D. 1991. Economic benefits of fumigants used in controlling insect pests in stored food. Food Market Commentary 12: 38-44.

White, N.D.G., and D.S. Jayas. 1991. Control of insects and mites with carbon dioxide in wheat stored at cool temperatures in non-airtight bins. J. Econ. Entomol. 84: 1933-1942.

White, N.D.G., and D.S. Jayas. 1993. Quality changes in grain under controlled atmosphere storage. In S. Navarro and E. Donahaye (eds.), Proceedings International Conference on Controlled Atmosphere and Fumigation in Grain Storage (in press).
White, N.D.G., and R.N. Sinha. 1990. Effect of chlorpyrifos-methyl on oat ecosystems in farm granaries. J. Econ. Entomol. 83: 11281134.

White, N.D.G., R.N. Sinha, and W.E. Muir. 1982. Intergranular carbon dioxide as an indicator of biological activity associated with the spoilage of stored wheat. Can. Agric. Eng. 24: 35-42.

White, N.D.G., D.S. Jayas, and R.N. Sinha. 1988. Interaction of carbon dioxide and oxygen levels, and temperature on adult survival and reproduction of Cryptolestes ferrugineus in stored wheat. Phytoprotection 69: 31-39.

White, N.D.G., D.S. Jayas, and R.N. Sinha. 1990. Carbon dioxide as a control agent for the rusty grain beetle (Coleoptera: Cucujidae) in stored wheat. J. Econ. Entomol. 83: 277-288.

White, N.D.G., D.S. Jayas, W.E. Muir, and R.N. Sinha. 1993. Controlled atmosphere storage research and technology in Canada. In S. Navarro and E. Donahaye (eds.), Proceedings International Conference on Controlled Atmosphere and Fumigation in Grain Storage (in press). 